\title{
Relative distribution of gastrin-, CCK-8-, NPY- and CGRP-immunoreactive cells in the digestive tract of dorado (Salminus brasiliensis)
}

\author{
R.T. Pereira ${ }^{a, *}$, L.S. Costa ${ }^{a}$, I.R.C. Oliveira ${ }^{b, d}$, J.C. Araújo ${ }^{c}$, M. Aerts ${ }^{d}$, F.A. Vigliano ${ }^{e}$, \\ P.V. Rosa ${ }^{a}$ \\ a Department of Animal Science/Fish Nutrition, Federal University of Lavras UFLA, Lavras, MG, Brazil \\ ${ }^{\mathrm{b}}$ Department of Exact Sciences, ESALQ/USP, 13418-900, Piracicaba, SP, Brazil \\ ' EMBRAPA Amapá, Aquaculture, Brazil \\ d I-BioStat, Hasselt University, B-3500 Hasselt, Belgium \\ e Cátedra de Histología y Embriología, Facultad de Ciencias Veterinarias, Universidad Nacional de Rosario/Consejo Nacional de Investigaciones Científicas y \\ Técnicas (CONICET), Argentina
}

\section{A R T I C L E I N F O}

\section{Article history:}

Received 1 December 2014

Received in revised form 29 January 2015

Accepted 30 January 2015

Available online 27 February 2015

\section{Keywords:}

Endocrine cells

Immunohistochemistry

Intestine

Mixed modeling

Neuropeptides

\begin{abstract}
A B S T R A C T
The endocrine cells (ECs) of the gastrointestinal mucosa form the largest endocrine system in the body not only in terms of cell numbers but also in terms of the different produced substances. Data describing the association between the relative distributions of the peptide-specific ECs in relation to feeding habits can be useful tools that enable the creation of a general expected pattern of EC distribution. We aimed to investigate the distribution of ECs immunoreactive for the peptides gastrin (GAS), cholecystokinin (CCK-8), neuropeptide Y (NPY), and calcitonin gene-related peptide (CGRP) in different segments of the digestive tract of carnivorous fish dorado (Salminus brasiliensis) by using immunohistochemistry procedures. The distribution of endocrine cells immunoreactive for gastrin (GAS), cholecystokinin (CCK8), neuropeptide Y (NPY), and calcitonin gene-related peptide (CGRP) in digestive tract of dorado $S$. brasiliensis was examined by immunohistochemistry. The results describe the association between the distribution of the peptide-specific endocrine cells and feeding habits in different carnivorous fish. The largest number of endocrine cells immunoreactive for GAS, CCK-8, and CGRP were found in the pyloric stomach region and the pyloric caeca. However, NPY-immunoreactive endocrine cells were markedly restricted to the midgut. The distribution pattern of endocrine cells identified in S. brasiliensis is similar to that found in other carnivorous fishes.
\end{abstract}

(c) 2015 Elsevier Ltd. All rights reserved.

\section{Introduction}

The diffuse neuroendocrine system (DNES) comprises several types of gastrointestinal cells that produce and secrete different peptides. These peptides have several effects on the digestive process and feeding behavior (Toni, 2004; Jensen, 2001). The endocrine cells (ECs) of the gastrointestinal mucosa form the largest endocrine

Abbreviations: DNES, diffuse neuroendocrine system; GAS, gastrin; CCK-8, cholecystokinin; NPY, neuropeptide Y; CGRP, calcitonin gene-related peptide; ECs, endocrine cells; PS, pyloric stomach region; PC, pyloric caeca; FL, first loop of medium intestine; SL, second loop of medium intestine; PI, posterior intestine.

* Corresponding author at: Department of Animal Science/Fish Nutrition, Federal University of Lavras UFLA, Postal Code 3037, CEP 37200-000 Lavras, MG, Brazil. Tel.: +55 359189 0280; fax: +55 3538291231 .

E-mail address: raqueltpr@gmail.com (R.T. Pereira). system in the body, not only in terms of cell numbers but also in terms of the different produced substances (Ahlman and Nilsson, 2001).

Studies performed in the past decade have described the distribution and the relative frequency of the DNES cells in the gastrointestinal tracts of various species of fish that present different feeding habits (Webb et al., 2010; Çinar et al., 2006; Tarakçi, 2005; Bosi et al., 2004; Pan et al., 2000a,b). However, an expected general pattern of distribution for these ECs along the digestive tract that would enable any association between feeding habits and the type of peptide produced is still not available.

Anatomical and morphological features of the digestive tract were used to explain the distribution patterns of cholecystokinin (CCK) in fish during post-larval development. The model suggested that the distribution pattern of CCK is different between fish that present coiled and straight intestines (Rønnestad et al., 2003, 2007; 
Kamisaka et al., 2005). It is now clear that the anatomy and morphology of the fish digestive tract has a close relationship with it feeding habits. In simple terms, carnivorous fish usually have large stomachs and short intestines, whereas omnivorous and herbivorous fish usually have small or medium stomachs and long, coiled intestines.

As a consequence of extraordinary diversity types of peptides and of the modest number of species that have actually been examined, our knowledge regarding the gastrointestinal endocrine systems in fishes remains limited. For this reason, results describing the association between the relative distributions of the peptidespecific ECs in relation to feeding habits could be useful tools that enable the creation of a general expected pattern of EC distribution and aid the better understanding of the physiology of the gastrointestinal endocrinology in fish.

Dorado Salminus brasiliensis (Cuvier 1816) is a carnivorous species of fish that is highly appreciated for the excellent quality of its meat and its great potential for aquaculture, sport fishing, and ornamental fishery (Mai and Zaniboni Filho, 2005; Vega-Orellana et al., 2006). It is the largest fish scale found in the Plata basin of Latin America (Morais Filho and De Schubart, 1955). S. brasiliensis presents the typical anatomical and morphological features of a carnivorous fish. The esophagus is wide and short, and the stomach is Y-shaped, with short cardiac and pyloric regions and very developed smooth muscle. The intestine is short, tubular, and presents the same diameter in its extension; it is located in the coelomic cavity, forming an $\mathrm{N}$ shape and consisting of 3 loops that end in the posterior intestine (PI). S. brasiliensis presents greatly developed pyloric caeca (PC), located at the beginning of the midgut (Rodrigues and Menin, 2008).

Among the peptides identified in the gut of fishes, some of them seem to play a key role in gastrointestinal physiology. Gastrin (GAS), CCK-8, calcitonin gene-related peptide (CGRP) and neuropeptide Y (NPY) are especially important because they exert generalized actions which regulate digestive processes and feeding behavior (López-Patiño et al., 1999; Jensen, 2001; Olsson and Holmgren, 2001; Martínez-Álvarez et al., 2009).

GAS, CCK-8 and CGRP are anorexigenic peptides expressed in ECs of the gastrointestinal mucosa (Hernández et al., 2012; Vigliano et al., 2011; Martínez-Álvarez et al., 2009; Bermúdez et al., 2007; Bjenning and Holmgren, 1988). CCK-8 stimulates gallbladder contraction, pancreatic enzyme secretion, gastrointestinal motility and inhibits gastric emptying (Jönsson et al., 2006; Holmgren and Olsson, 2009; Jensen and Holmgren, 1994; Himick and Peter, 1994). GAS regulates gastric secretion and motility (Forgan and Forster, 2007; Volkoff et al., 2005). CGRP is also expressed in neurons and nerve fibers of myenteric plexus (Vigliano et al., 2011; MartínezÁlvarez et al., 2008; Ogoshi et al., 2006; Lafont et al., 2004; Clark et al., 2002) where acts inhibiting intestinal motility (Shahbazi et al., 1998). In addition, both CCK-8 and CGRP are expressed in the brain of fish (Holmgren and Olsson, 2009; Kurokawa et al., 2003).

NPY is a highly conserved peptide and is the most potent orexigenic factor known in mammals (Chee and Colmers, 2008; Larhammar, 1996; Larhammar et al., 1998; Dumont et al., 1992). This peptide is mainly expressed in the hypothalamic neurons and in the ECs of the gastrointestinal tract (Yokobori et al., 2012; Hernández et al., 2012; MacDonald and Volkoff, 2009; Kehoe and Volkoff, 2007). NPY regulates feeding behavior and is a potent stimulator of food intake in fish (MacDonald and Volkoff, 2009; Peddu et al., 2009; Narnaware and Peter, 2001; Silverstein et al., 1999).

The aim of the present study was to analyze the relative distribution of ECs that are immunopositive for GAS, CCK-8, NPY, and CGRP in different segments of the digestive tract of dorado $S$. brasiliensis using immunohistochemistry.

\section{Materials and methods}

\subsection{Fishes and sampling procedures}

Twelve fourteen month-old juveniles of $S$. brasiliensis with an average initial length of $25.5 \pm 3.5 \mathrm{~cm}$, mean weight of $144.83 \pm 21.7 \mathrm{~g}$, regardless of gender and obtained from the Reproduction Unit of CEMIG (Electrical Company of Minas Gerais, Itutinga, Minas Gerais, Brazil) were used in the present study. The experiment was conducted at the Aquaculture Unit of the Department of Animal Sciences, Federal University of Lavras, Brazil.

Fish were acclimated during a 6 -month period in a masonry $\operatorname{tank}(8 \mathrm{~m} \times 5 \mathrm{~m}$ and $1.6 \mathrm{~m}$, length, wide and deep) with daily water renewal rate of $20 \%$ and dissolved oxygen between 4 and $6 \mathrm{mgl}^{-1}$. The average water temperature in winter was 16 and $28^{\circ} \mathrm{C}$ in summer. The temperature parameters, dissolved oxygen and toxic ammonia were monitored daily at the beginning and end of the day and stayed within welfare standards appropriate for this fish species.

The fish was fed with a commercial food containing $40 \%$ crude protein (Guabi; www.guabi.com.br) that was offered twice a day until apparent satiation. After a 24-hour fasting period, fishes were euthanized with an overdose of Benzocaine $250 \mathrm{mgl}^{-1}$ (Sigma; www.sigmaldrich.com), and their spinal cords were sectioned.

Cross-sections ( $5 \mathrm{~mm}$ length) were removed from the digestive tract, including the pyloric stomach region(PS), different segments of the midgut including the pyloric caeca (PC), the first loop (FL), and the second loop (SL), and the posterior intestine (PI), as described by Rodrigues and Menin (2008). Tissue samples were fixed in Bouin solution for $12 \mathrm{~h}$ and then stored in $70 \%$ ethanol until processing. All procedures applied to fish were properly analyzed and authorized by the Animal Ethics Committee of the Federal University of Lavras, under the protocol number 013/2012.

\subsection{Light microscopy and immunohistochemistry}

Samples were dehydrated in ethanol, diaphonized in xylene, and embedded in paraffin wax. Histological sections (3-4 $\mu \mathrm{m}$ in thickness) were obtained, placed on silanized slides, and dried in a $37^{\circ} \mathrm{C}$ oven overnight. The histological sections were stained with hematoxylin and eosin to morphology evaluation of the structures and to measure the area of the mucosal epithelium, according to routine histological methods Bancroft et al. (2008).

For immunohistochemistry, all incubations were performed in a humid chamber and all washing procedures consisted of 3 successive immersions in $0.1 \mathrm{M}$ phosphate buffered saline (PBS), $\mathrm{pH}$ 7.20 , for $5 \mathrm{~min}$. The endogenous peroxidase activity was blocked for 30 minutes by Peroxidase Block reagent (DakoCytomation, USA). Non-specific antibody binding was blocked in 2 ways: incubation of the sections in 5\% non-fat dry milk in PBS for $5 \mathrm{~min}$ and incubation of the sections in Block Serum reagent (DakoCytomation, USA) for $15 \mathrm{~min}$. Following the blocking step, the histological sections were incubated with rabbit polyclonal primary antibodies (Vigliano et al., 2011) as presented in Table 1. After wash in PBS, the anti-rabbit IgG secondary antibody incubation (EnVision + System/HRP, DakoCytomation, USA) was applied for 30 minutes. The reactions were detected through the enzymatic method, using 3,3'-diaminobenzidine tetrahydrochloride (DakoCytomation, USA) for $25 \mathrm{~s}$ and counterstaining with Carazzi's hematoxylin. Intestine histological sections of South American catfish Rhamdia quelen (Quoy \& Gaimard, 1824) were included as positive controls and the negative controls consisted of the omission of primary antibody (replaced by PBS).

Although the antibodies were developed in mammals, these antibodies were chosen because they successfully identified the same peptides in the cells of the DNES before in $R$. quelen 
Table 1

Antibodies used in the present study to localize peptides in dorado (Salminus brasiliensis).

\begin{tabular}{llll}
\hline $\begin{array}{l}\text { Polyclonal } \\
\text { antibody against }\end{array}$ & $\begin{array}{l}\text { Antibody working } \\
\text { dilution }\end{array}$ & $\begin{array}{l}\text { Incubation } \\
\text { variables }\end{array}$ & Source (code) \\
\hline GAS (human) & $1: 600$ & $3 \mathrm{~h}, \mathrm{RT}$ & Bachem $^{\mathrm{a}} \mathrm{T}-4347$ \\
CCK-8 (synthetic) & $1: 1000$ & $3 \mathrm{~h}, \mathrm{RT}$ & Bachem $^{\mathrm{a}} \mathrm{T}-4254$ \\
NPY (swine) & $1: 1500$ & ON, $4^{\circ} \mathrm{C}$ & Bachem $^{\mathrm{a}} \mathrm{T}-4454$ \\
CGRP (rat) & $1: 800$ & ON, $4^{\circ} \mathrm{C}$ & Bachem $^{\mathrm{a}} \mathrm{T}-4032$ \\
\hline
\end{tabular}

GAS, gastrin; CCK-8, cholecystokinin-8; NPY, neuropeptide Y; CGRP, calcitonin generelated peptide; ON, over night; $\mathrm{RT}$, room temperature $\left(22-25^{\circ} \mathrm{C}\right)$.

a www.bachem.com.

(Hernández et al., 2012), Argentinean silverside Odontesthes bonariensis (Valenciennes, 1835) (Vigliano et al., 2011), and turbot Psetta maxima (Linnaeus, 1758) (Bermúdez et al., 2007), indicating the similarity and conservation of these peptides between mammals and fish. The cross-reactivity strongly suggests that peptides in teleosts fishes share similar or even identical epitopes with their equivalents in higher vertebrates (Langer et al., 1979).

In addition, because the antibodies used were not developed against the $S$. brasiliensis peptides, a comparison analysis of the protein sequences available in the database of the National Center for Biotechnology Information (NCBI: http://www.ncbi.nlm.nih.gov/protein) was performed prior to the present study to assess whether the similarities between the amino acid sequences occurred by chance. To date, no sequences for the $S$. brasiliensis peptides are available; thus, it was necessary to use sequences from other species of fish. Data available at NCBI included Nile tilapia Oreochromis niloticus (Linnaeus, 1758), goldfish Carassius auratus (Linnaeus, 1758), zebrafish Danio rerio (Hamilton, 1822), Atlantic salmon Salmo salar (Linnaeus, 1758), rainbow trout Oncorhynchus mykiss (Walbaum, 1792), channel catfish Ictalurus punctatus (Rafinesque, 1818), white seabream Diplodus sargus (Linnaeus, 1758) and bastard halibut Paralichthys olivaceus (Temminck \& Schlegel, 1846). The comparisons between protein sequences were performed using the basic local alignment search tool (BLAST) of National Institute of Mental Health, NIMH (2011). In all cases, the similarity values obtained were greater than $80 \%$, and in most of the comparisons, the E values were very small, indicating that the variations in the sequences do not occur randomly.

Moreover, in each immunohistochemistry assay, the morphology of the cell types that were immunostained showed the typical expected features when compared to those from other species of fish and mammals.

\subsection{Cell counting and statistical analysis}

The average number of ECs per $\mathrm{mm}^{2}$ of mucosal epithelium (ECs $\mathrm{mm}^{-2}$ ) was determined by cell counting and measuring the mucosal epithelium area. Immunopositive cells were counted using the microscope, while the mucosal epithelium area was measured using a morphometric analysis software, Image J, version 1.46a (Wayne, Research Services Branch 2011). The average number of

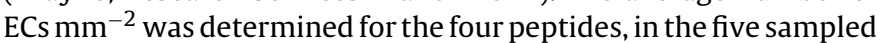
segments from each of the twelve juveniles of $S$. brasiliensis. These segments were sampled according to a natural order, from beginning to the end of the intestine. All slides were photographed and analyzed with a CX31 light microscope (Olympus, Japan) coupled to Altra SC30 digital camera (Olympus, Japan).

It is intuitive to assume that observations obtained from the same fish are correlated and, in contrast to what is found in the literature, these measures cannot be considered independent and, hence, analyzed using classical ANOVA and/or traditional multiple comparisons tests. The number of ECs was analyzed using linear mixed models, a flexible methodology for dealing with repeated measurements and longitudinal data (Pinheiro and Bates, 2009; Verbeke and Molenberghs, 2000). The individual profiles were approximated by an estimated mean, using repeated measures ANOVA after transforming the original response scale logarithmically using the program SAS version 9.1 (SAS Institute, 2000).

The effects of the segments on the quantity of ECs immunoreactive to each peptide were examined, considering the mixed effect model:

$y_{i j}=\mu+d_{i}+\delta_{j}+\varepsilon_{i j}$,

where $y_{i j}$ is $\log$ (number of ECs per $\mathrm{mm}^{2}$ of mucosal epithelial immunoreactive to the peptides +1 ) of fish $i$ and segment $j$, for $i=1$, $\ldots, 12$ and $j=1, \ldots, 5, \mu$ is a constant common to all observations, $d_{i}$ is the random effect related to fish $i$, where $d_{i} \sim N\left(0, \sigma_{d}^{2}\right), \delta_{j}$ is the effect related to segment $j$, and $\varepsilon_{i j} \sim N\left(0, \sigma^{2}\right)$.

\section{Results}

\subsection{Diffuse neuroendocrine system}

The immunolocalization of GAS, CCK-8, NPY, and CGRP in different cell types in the digestive tract of $S$. brasiliensis was determined for the first time. Immunostaining for the peptides was observed in the DNES and in cells and structures of the enteric nervous system.

Immunoreactivity for each antibody used was observed in ECs scattered among the gastric epithelial cells and among the enterocytes in the intestinal epithelium of $S$. brasiliensis (Fig. 1). ECs presented a distinct morphology. In the PS region exhibited a polyhedral shape with a rounded nucleus and were mainly located at the base of the stomach mucosal folds (Fig. 1a, c, e, and g, inset). On the other side, in all sampled region of the intestine ECs showed an elongate or triangular shape, with their base wider than their apex, and a rounded or oval nucleus in center or basal position (Fig. 1b, d, $\mathrm{f}$, and h, inset). Some ECs in the intestine presented one or two cytoplasmic processes toward the lumen and in the opposite direction, toward the base of the cell. Similar observations regarding the morphological patterns of ECs were also described for other fish species (Hernández et al., 2012; Vigliano et al., 2011; Lee et al., 2004; Pan et al., 2000b).

Summary statistics that describe, in general, the presence of the peptides along the intestinal tract of $S$. brasiliensis are displayed in Table 2. All descriptive statistics were obtained from the original data and over all fishes. The percentages refer to the proportion of cells immunoreactive to each antibody in each segment with respect to the total of cells recorded in the whole gut.

Different structures of the covariance matrix were examined, but the variance components structure was more parsimonious and had a high goodness-of-fit. In the model diagnostic no outliers were detected and the normality assumptions for the errors were met. Significant effects of the segments in the log (number of ECs $\mathrm{mm}^{-2}+1$ ) were detected for all the peptides (Table 3 ). This variation in the distribution of ECs $\mathrm{mm}^{-2}$ according to the different segments of the digestive tract and associated with different feeding habits was also reported in other fish species (Bosi et al., 2006; Lee et al., 2004; Pan et al., 2000b).

The immunolocalization of GAS demonstrated the presence of ECs from the PS to the PI (Fig. $1 \mathrm{a}$ and $\mathrm{b}$ ). The largest number of GAS+ ECs $\mathrm{mm}^{-2}$ was found in the PS, followed by the FL, with $62.7 \%$ and $13.6 \%$ of the total, respectively (Fig. 2 and Table 2). Considering the sampled segments, the number of GAS+ECs $\mathrm{mm}^{-2}$ decreased over the intestine, with respect to the quantity in the PS (Table 3), and the lower density was in the PI. Thus, small amounts of GAS+ ECs $\mathrm{mm}^{-2}$ were identified at the end of the intestine. 


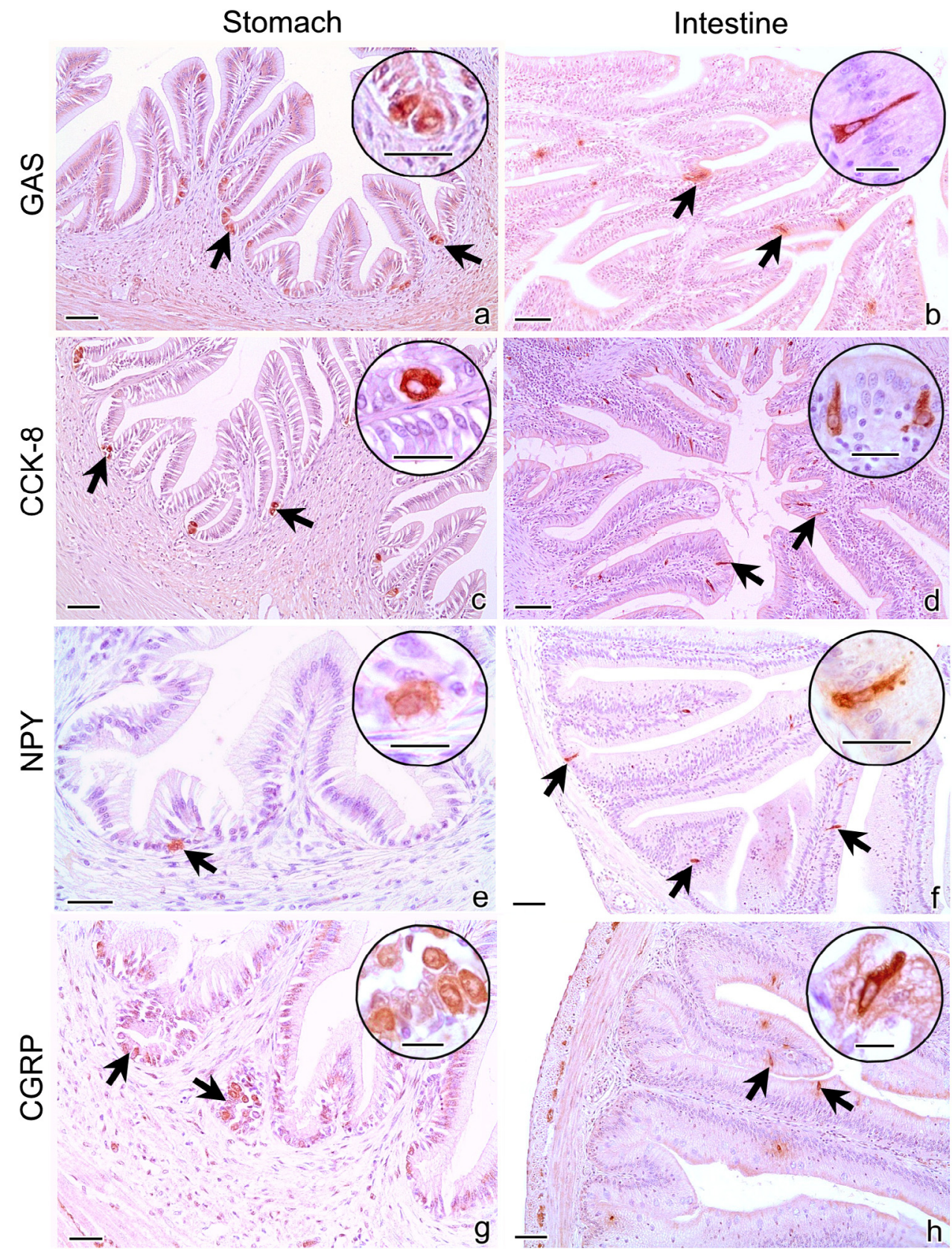

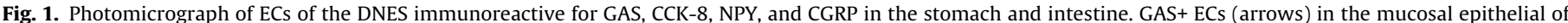

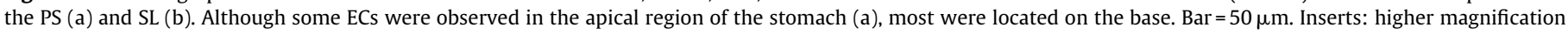

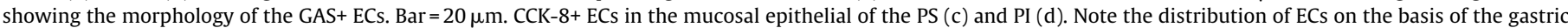

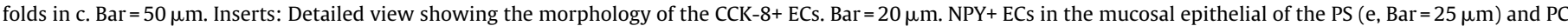

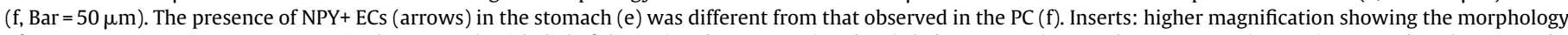

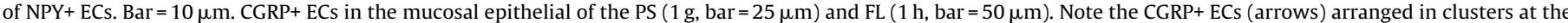
base of the gastric folds. Inserts: higher magnification showing the morphology of CGRP+ ECs. Bar $=10 \mu \mathrm{m}$.

CCK-8 was identified in ECs in all sampled segments. A higher number of $\mathrm{CCK}-8+\mathrm{ECs} / \mathrm{mm}^{-2}$ was found in the PS, which represented $44.4 \%$ of the total, as was observed for GAS in relation to all other segments (Fig. 2 and Table 2). Also, the numbers of CCK-8+ ECs $\mathrm{mm}^{-2}$ decreased over PC, FL, SL, and PI (Table 3 ). The quantity of CCK-8+ ECs $\mathrm{mm}^{2}$ was constant over the segments PC and FL. $55.5 \%$ of the total of CCK-8+ ECs was observed in the segments of the midgut and of the posterior intestine.

NPY+ ECs immunolocalization revealed a limited distribution. The largest number of NPY+ECs $\mathrm{mm}^{-2}$ was concentrated in the segments of the midgut that comprise the PC, FL, and SL (Fig. 2 and Table 3). These three segments, together, represented $97.3 \%$ of the total NPY+ ECs. Small quantities of NPY+ ECs $\mathrm{mm}^{-2}$ were observed in the PS and PI.

CGRP was expressed in ECs in all analyzed segments. The highest density of CGRP+ ECs $\mathrm{mm}^{-2}$ was found in the PS, which corresponded to $68.1 \%$ of the total, a result similar to the GAS and CCK-8. Segments of the PC, FL, and SL showed an intermediate number of CGRP+ ECs $\mathrm{mm}^{-2}$ (Fig. 2 and Table 2). Significant reductions in the number of ECs were mainly observed in the PC and IP (Table 3). 
Table 2

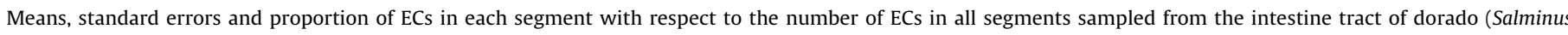
brasiliensis), over all fishes.

\begin{tabular}{|c|c|c|c|c|c|}
\hline \multirow[t]{2}{*}{ Peptide } & \multicolumn{2}{|l|}{ Stomach } & \multicolumn{2}{|l|}{ Midgut } & \multirow{2}{*}{$\begin{array}{l}\text { Posterior } \\
\text { intestine } \\
\text { IP }\end{array}$} \\
\hline & PS & PC & $\mathrm{FL}$ & $\mathrm{SL}$ & \\
\hline \multirow[t]{2}{*}{ GAS } & $83.70(10.27)$ & $14.88(1.95)$ & $18.17(2.32)$ & $12.34(1.65)$ & $4.33(0.98)$ \\
\hline & $62.7 \%$ & $11.2 \%$ & $13.6 \%$ & $9.2 \%$ & $3.2 \%$ \\
\hline \multirow[t]{2}{*}{ CCK-8 } & $55.80(7.63)$ & $22.16(3.56)$ & $21.77(2.82)$ & 15.25 (1.77) & $10.64(2.44)$ \\
\hline & $44.4 \%$ & $17.6 \%$ & $17.3 \%$ & $12.1 \%$ & $8.5 \%$ \\
\hline \multirow[t]{2}{*}{ NPY } & $0.85(0.46)$ & $29.89(2.52)$ & $48.43(5.80)$ & $36.08(4.75)$ & $2.25(1.41)$ \\
\hline & $0.7 \%$ & $25.4 \%$ & $41.2 \%$ & $30.7 \%$ & $1.9 \%$ \\
\hline \multirow[t]{2}{*}{ CGRP } & $55.85(5.24)$ & $6.35(1.35)$ & $11.03(1.72)$ & $6.96(0.77)$ & $1.46(0.75)$ \\
\hline & $68.1 \%$ & $8.3 \%$ & $13.5 \%$ & $8.5 \%$ & $1.6 \%$ \\
\hline
\end{tabular}

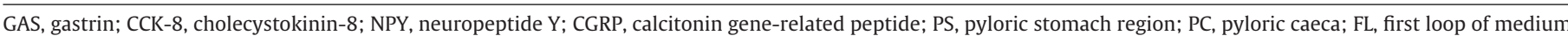
intestine; SL, second loop of medium intestine; PI, posterior intestine.

Table 3

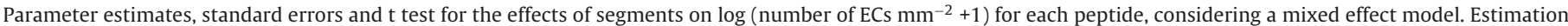
was done by maximum likelihood.

\begin{tabular}{|c|c|c|c|c|c|}
\hline \multirow[t]{2}{*}{ Effect } & \multirow[t]{2}{*}{ Param. } & \multicolumn{4}{|c|}{ Estimate (standard error) } \\
\hline & & GAS & CCK & NPY & CGRP \\
\hline PS & $\delta_{1}$ & $1.91(0.06)^{*}$ & $1.73(0.07)^{*}$ & $0.16(0.08)^{* *}$ & $1.73(0.08)^{*}$ \\
\hline PC & $\delta_{2}$ & $1.17(0.06)^{*}$ & $1.33(0.07)^{*}$ & $1.47(0.07)^{*}$ & $0.79(0.07)^{*}$ \\
\hline FL & $\delta_{3}$ & $1.25(0.05)^{*}$ & $1.31(0.07)^{*}$ & $1.67(0.08)^{*}$ & $1.03(0.07)^{*}$ \\
\hline SL & $\delta_{4}$ & $1.09(0.05)^{*}$ & $1.18(0.07)^{*}$ & $1.54(0.08)^{*}$ & $0.88(0.07)^{*}$ \\
\hline PI & $\delta_{5}$ & $0.67(0.06)^{*}$ & $0.96(0.07)^{*}$ & $0.27(0.07)^{*}$ & $0.26(0.07)^{*}$ \\
\hline Variance random effect & $\sigma_{d}^{2}$ & 0.0082 & 0.0215 & 0.0095 & 0.0111 \\
\hline Variance & $\sigma^{2}$ & 0.0251 & 0.0295 & 0.0539 & 0.0419 \\
\hline
\end{tabular}

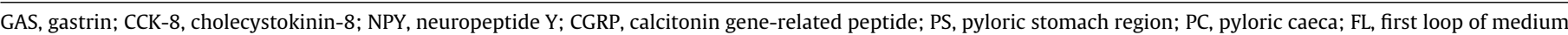
intestine; SL, second loop of medium intestine; PI, posterior intestine.

${ }^{*} p<0.0001$.

** $p<0.0005$.

GAS

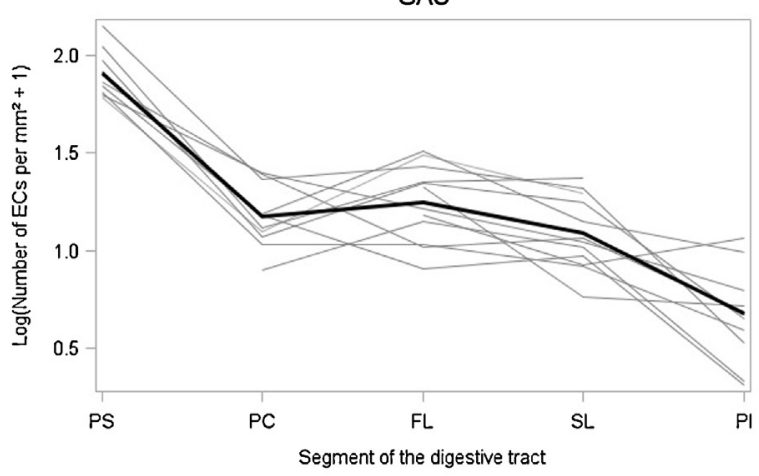

NPY

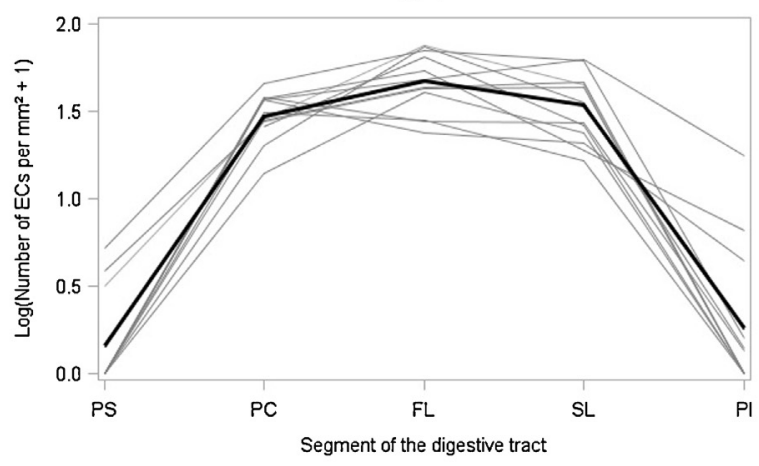

CCK

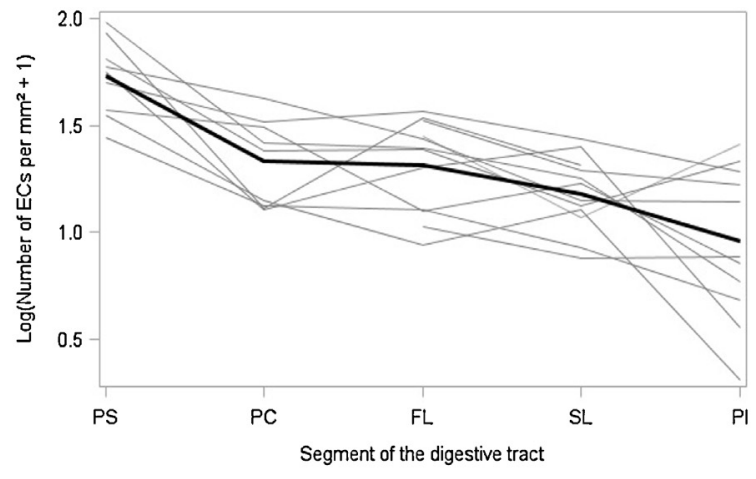

CGRP



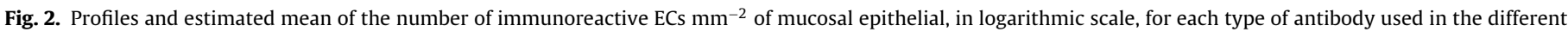
segments of the digestive tract. 
When analyzed together, the PC, FL, and SL segments corresponded to $30.3 \%$ of total CGRP+ ECs $\mathrm{mm}^{-2}$ and the lowest density of ECs was detected in the PI, representing, approximately, $1.6 \%$ of the total. Therefore, the highest density of CGRP+ ECs occurred in the PS and was significantly reduced over the following segments.

\subsection{Enteric nervous system}

Positive immunoreactivity for CGRP and NPY was observed in the myenteric plexus. Neurons and nerve fibers immunoreactive for CGRP were observed in the myenteric plexus of all sampled segments of the PS, PC, FL, SL, and PI (Fig. 3a-c). This location may indicate the intrinsic origin of the peripheral signals that start at the enteric nervous system.

\section{Discussion}

In Atlantic cod Gadus morhua (Linnaeus, 1758) GAS+ ECs were more numerous in the PC, followed by the PS and the beginning of the midgut. Few ECs were present in other parts of the intestine (Jönsson et al., 1987). For shorthorn sculpin Myoxocephalus scorpius (Linnaeus 1758), few GAS+ ECs were present in the PS; however, large numbers of cells were observed in the beginning, middle, and in the end of the midgut (Holmgren and Olsson, 2009; Bjenning and Holmgren, 1988). A study analyzing different portions of raibow trout O. mykiss (Walbaum, 1792) stomach (Barrenechea et al., 1994) identified numerous GAS+ ECs only in the PS. Immunohistochemical analyses of the digestive tracts of other carnivorous fish, such as sea trout Salmo trutta (Linnaeus, 1758), also reported GAS+ ECs in the caecal region, the PS, the PC, and the beginning of the midgut. For $S$. trutta, the GAS+ ECs were more numerous in the PS and the PC. Few ECs were present in the caecal region and in the beginning of the intestine, while no cells were identified in the distal segment of the midgut and PI (Bosi et al., 2004).

The primary signals to reduce the gastric emptying rate after the arrival of food in the intestine are the release of CCK by the duodenum and the release of GAS in the stomach (Holmgren and Olsson, 2009; Vigna, 2000). Thus, the distribution pattern of GAS+ ECs, concentrated in the PS and adjacent to the PC in the intestine of $S$. brasiliensis, can indicate a strategic location for GAS to exert its physiological functions, which included the stimulation of gastric secretions, the relaxation of the pyloric sphincter, and increased motility (Holmgren and Olsson, 2009).

As in S. brasiliensis, in G. morhua CCK+ ECs were most numerous in the PC, followed by the PS and the beginning of the midgut. Few ECs were present in other parts of the intestine (Jönsson et al., 1987). In a study performed in different segments of the $O$. mykiss stomach, numerous CCK+ ECs were identified only in the PS (Barrenechea et al., 1994).

In immunohistochemical studies in the digestive tract of $S$. trutta, CCK-8+ ECs were found in the PC and midgut. The highest density of cells in S. trutta was described in the initial segment of the midgut, while a moderate amount of cells were present in the PC and in the distal segment of the midgut. In S. trutta, CCK+ ECs were not found in the stomach or PI (Bosi et al., 2004).

Similar to S. trutta, in Coreoperca herzi (Herzenstein, 1896), CCK8+ ECs were detected only in the midgut (Lee et al., 2004). In P. maxima, CCK-8+ ECs were more numerous and were primarily found in the PC and in the initial segment of the midgut. CCK-8+ECs were not detected in the stomach or the PI of P. maxima (Bermúdez et al., 2007). Reports of the early presence of CCK-8+ECs in red drum Sciaenops ocellatus (Linnaeus, 1766) larvae at 26 days indicate that ECs are more abundant in the PC, sparse in the midgut, and absent in the stomach and PI (Webb et al., 2010).
Anatomical and morphological features of the digestive tract have been used to explain the distribution pattern of CCK in fish during and after larval development. An expected distribution model was proposed based on coiled intestine versus straight intestine (Webb et al., 2010; Rønnestad et al., 2007). In this model, the distribution pattern of CCK+ cells is closely related to the presence or absence of a coiled intestine (Rønnestad et al., 2003, 2007; Kamisaka et al., 2005). In fish larvae that have coiled intestines, $\mathrm{CCK}+$ cells are concentrated primarily in the initial segment of the midgut and in the PC (Kamisaka et al., 2001, 2002; Kurokawa et al., 2000). In fishes that have a straight intestine, such as Atlantic herring Clupea harengus (Linnaeus, 1758), in situ hybridization studies have demonstrated that the cells expressing CCK mRNA were scattered throughout the entire intestine, with no significant concentration areas (Kamisaka et al., 2005), as observed in the present study with $S$. brasiliensis.

The high concentration of CCK+ ECs in the PS region and in the region adjacent to the $P C$ in $S$. brasiliensis suggests the important function of CCK in this portion of the digestive tract in fish (Webb et al., 2010). These digestive tract segments represent a strategic region, because they comprise the end of the stomach, the beginning of the intestine, and the insertion of the PC, and it is also the area where the pancreatic and bile ducts end. Considering the primary functions attributed to CCK (Jensen and Holmgren, 1994), the highest density of CCK-8+ ECs near the pyloric sphincter and the PC in $S$. brasiliensis suggest that these might be key locations for this peptide to regulate the passage of digested food from the stomach to the PC and to promote the proper release of bile and pancreatic secretions, similar to that reported for S. ocellatus larvae (Webb et al., 2010). In addition, CCK has been indicated to stimulate reverse peristalsis, which can be a mechanism for facilitating the filling of the PC and contribute to mix the digested food and enzymes (Rønnestad et al., 2000, 2007; Olsson and Holmgren, 2001).

Studies of the gastrointestinal tract in I. punctatus (Min et al., 2009) and Pseudophoxinus antalyae (Bogutskaya, 1992) (Çinar et al., 2006) also demonstrated that, although rare, NPY+ ECs were concentrated in the epithelial mucosa of the midgut and no cells were found in the stomach or the PI. In Anguilla anguilla, NPY+ ECs were also rare and were localized in the midgut and PI, with no immunoreactivity detected in the stomach (Domeneghini et al., 2000). Similar to that observed in I. punctatus, P. antalyae, common eel $A$. anguilla (L), and in S. brasiliensis in the present study, NPY+ ECs in $R$. quelen were quite numerous in the midgut, especially in its initial portion, and there was no immunoreactivity for NPY in the stomach (Hernández et al., 2012).

The midgut is the segment of the digestive tract with the greatest efficiency for the absorption of nutrients. Although there are differences among fish species, in the majority of fishes the distribution of the transporters decreases in the most distal segments of the intestine, and consequently, the absorption rate also decreases (Bakke et al., 2010; Buddington and Diamond, 1987). The high density of NPY+ ECs restricted to the midgut suggests that this peptide is strategically located in a region with higher absorption rate; thus, this region could effectively monitor the type and amount of nutrients absorbed. NPY is primarily expressed in the fish brain (Yokobori et al., 2012; MacDonald and Volkoff, 2009; CerdáReverter et al., 2000), and this peptide is a potent orexigenic factor in the CNS. However, its expression in the gastrointestinal system is also evident (Hernández et al., 2012; Vigliano et al., 2011; Çinar et al., 2006).

It appears that NPY does not have a specific role in the local digestive processes (Hoskins and Volkoff, 2012; Volkoff, 2006; Narnaware and Peter, 2001; Silverstein et al., 2001; López-Patiño et al., 1999). In this context, considering the distribution pattern of the NPY+ ECs and the fibers of the myenteric plexus in S. brasiliensis and similar findings in other carnivorous fish, it can be suggested 


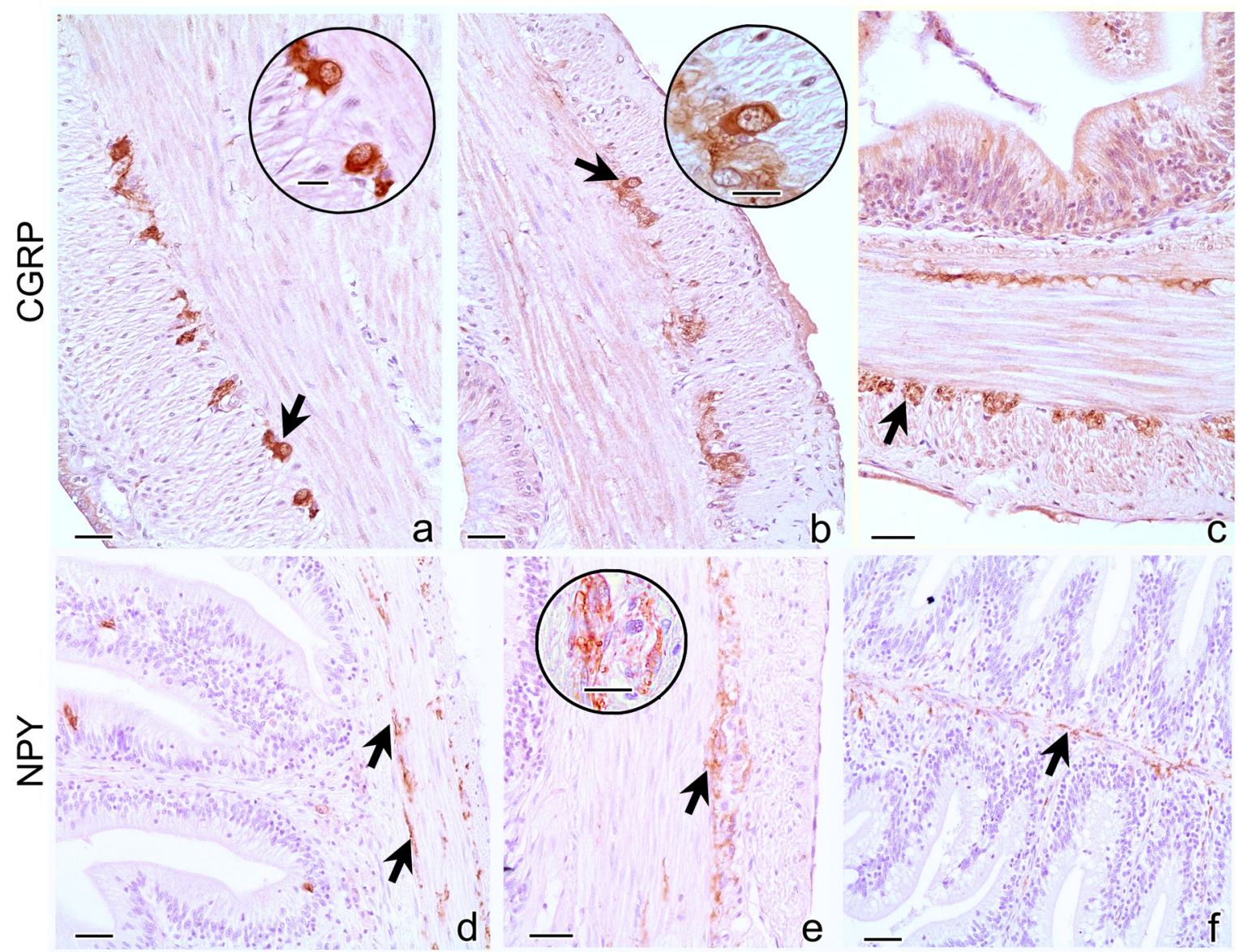

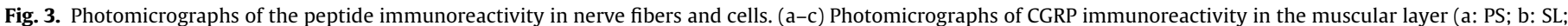

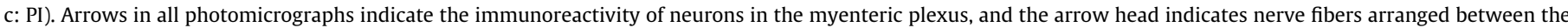

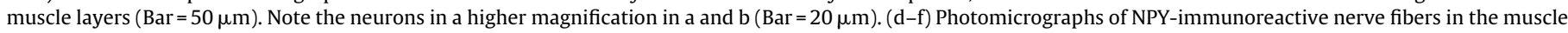

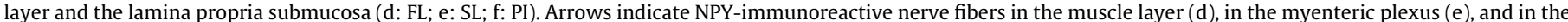

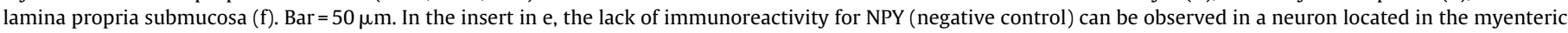
plexus. $\mathrm{Bar}=50 \mu \mathrm{m}$.

that the ECs producing NPY in the intestine are a source of signaling and peripheral monitoring to the hypothalamic center that in turn regulates food intake.

Similar results obtained in P. antalyae demonstrated that CGRP+ ECs were more abundant in the stomach and medium intestine, while a significant decrease occurred in the density of the PI (Çinar et al., 2006).

In contrast, in P. maxima, CGRP+ ECs were more abundant in the PC and the initial segment of the midgut, whereas few cells were observed in the intermediate segment of the midgut. No CGRP+ ECs were found in stomach or in the PI (Bermúdez et al., 2007). Similar to P. maxima, in R. quelen the CGRP+ ECs were observed, although rarely, only in the two first segments of the midgut. However, CGRP+ ECs were not visualized in the stomach, the final segment of the midgut or the rectum (Hernández et al., 2012).

In the present study, the peptide CGRP was distributed in the myenteric plexus in all sampled segments of the digestive tract and in ECs concentrated in the PS of $S$. brasiliensis. The primary effects of CGRP in fish include the inhibition of gastrointestinal motility and the inhibition of food intake (Martínez-Álvarez et al., 2009; Shahbazi et al., 1998). Based on the results of immunohistochemical analyses in S. brasiliensis and other fish, the distribution pattern of CGRP+ ECs near the end of the stomach (in the PS) and the beginning of the midgut may indicate a key localization since these regions are critical areas for controlling the flow of digested food between the stomach and intestine. Thus, the largest concentration of CGRP+
ECs would primarily occur in this portion to monitor the presence of chyme in the lumen and then signalize to the enteric nervous system, which regulates motor activity.

However, in the myenteric plexus and in the lamina propria submucosa, only nerve fibers exhibited positive immunostaining for NPY in the FL, SL, and PI segments (Fig. 3d-f). Similar immunostaining for NPY and CGRP in the myenteric plexus has been described in fish species such as R. quelen (Hernández et al., 2012), O. bonariensis (Vigliano et al., 2011), S. trutta (Dezfuli et al., 2000) and A. anguilla (Domeneghini et al., 2000), among others. However, there are still no reports regarding the physiological role of NPY in the local regulation of the digestive process in freshwater fish.

In summary, our data show that the use of antibodies raised against mammalian peptides was efficient in the immunolocalization of GAS, CCK-8, NPY, and CGRP in S. brasiliensis. Most peptides were identified in all sampled segments, although some were sparse in certain segments. GAS, CCK-8, and CGRP were concentrated primarily in the PS and the PC. NPY was remarkably restricted to the midgut of the $S$. brasiliensis.

The immunolocalization of the modulating peptides GAS, CCK-8, NPY, and CGRP in ECs in the digestive tract of $S$. brasiliensis showed a distribution pattern similar to that observed in other carnivore species. Although particularities exist among species, in general, it appears that there is a distribution pattern that can partially be justified by the feeding habits of the species and the anatomical and morphological features of the digestive system. Thus, an association 
between peptide and feeding habits (carnivores or omnivores) can result in an expected location of this peptide in the digestive tract.

Given the complexity and extensive variety of intrinsic and extrinsic factors that can modulate the DNES, further studies are needed to better understand the factors that determine the distribution pattern of these peptides along the digestive tract of fish.

\section{Acknowledgements}

This work was supported by the Coordination for the Improvement of Higher Education Personnel (Coordenação de Aperfeiçoamento de Pessoal de Nível Superior - CAPES), the National Council for Scientific and Technological Development (Conselho Nacional de Desenvolvimento Científico e Tecnológico - CNPq), the Minas Gerais State Research Foundation (Fundação de Amparo à Pesquisa do Estado de Minas Gerais - FAPEMIG), and the Ministry of Education of Argentina (Program for the Argentinean Universities Promotion - Fifth call for Projects of Strengthen Inter-college students Network). Financial support was given to Priscila Vieira Rosa and Fabricio Vigliano.

\section{Appendix A. Supplementary data}

Supplementary data associated with this article can be found, in the online version, at http://dx.doi.org/10.1016/j.tice.2015.01.009.

\section{References}

Ahlman, H., Nilsson, O., 2001. The gut as the largest endocrine organ in the body. Ann. Oncol. 12, 63-68.

Bakke, A.M., Tashjian, D.H., Wang, C.F., Lee, S.H., Bai, S.C., Hung, S.S., 2010. Competition between seleno methionine and methionine absorption in the intestinal tract of green sturgeon Acipenser medirostris. Aquat. Toxicol. 96, 62-69, http://dx.doi.org/10.1016/j.aquatox.2009.09.014.

Bancroft, J.D., Stevens, A., Turner, D.R., 2008. Theory and Practice of Histological Techniques, 4th ed. Churchill Livingstone, London.

Barrenechea, M.A., Lopez, J., Martínez, A., 1994. Regulatory peptides in gastric endocrine cells of the rainbow trout Oncorhynchus mykiss: general distribution and colocalizations. Tissue Cell 26, 309-321, http://dx.doi.org/10.1016/0040-8166(94)90017-5.

Bermúdez, R., Vigliano, F., Quiroga, M.I., Nieto, J.M., Bosi, G., Domeneghini, C., 2007. Immunohistochemical study on the neuroendocrine system of the digestive tract of turbot, Scophthalmus maximus (L.), infected by Enteromyxum scophthalmi (Myxozoa). Fish Shellfish Immunol. 22, 252-263, http://dx.doi.org/10.1016/j.fsi.2006.05.006.

Bjenning, C., Holmgren, S., 1988. Neuropeptides in the fish gut. An immunohistochemical study of evolutionary patterns. Histochemistry 88, 155-163.

Bosi, G., Arrighi, S., Domeneghini, C., 2006. A comparative immunohistochemical study on a galanin-like peptide in the neuroendocrine system of the alimentary canal of three species of siluriform catfishes. J. Fish Biol. 68, 86-100, http://dx.doi.org/10.1111/j. 0022-1112.2006.01013.x.

Bosi, G., Giancamillo, A., Arrighi, S., Domeneghini, C., 2004. An immunohistochemical study on the neuroendocrine system in the alimentary canal of the brown trout, Salmo trutta, L., 1758. Gen. Comp. Endocrinol. 138, 166-181, http://dx.doi.org/10.1016/j.ygcen.2004.06.003.

Buddington, R.K., Diamond, J.M., 1987. Pyloric ceca of fish: a "new" absorption organ. Am. J. Physiol. 252, 65-76.

Cerdá-Reverter, J.M., Martínez-Rodríguez, G., Zanuy, S., Carrillo, M., Larhammar, D., 2000. Molecular evolution of the neuropeptide Y (NPY) family of peptides: cloning of three NPY-related peptides from the sea bass (Dicentrarchus labrax). Regul. Pept. 95, 25-34, http://dx.doi.org/10.1016/S0167-0115(00)00132-4.

Chee, M.J., Colmers, W.F., 2008. Y eat? Nutrition 24 (9), 869-877.

Çinar, K., Senol, N., Ozen, M.R., 2006. Immunohistochemical study on distribution of endocrine cells in gastrointestinal tract of flower fish (Pseudophoxinus antalyae). World J. Gastroenterol. 12, 6874-6878, http://dx.doi.org/10.3748/wjg.v12.i42.6874.

Clark, M.S., Bendell, L., Power, D.M., Warner, S., Elgar, G., Ingleton, P.M., 2002. Calcitonin: characterisation and expression in a teleost fish, Fugu rubripes. J. Mol. Endocrinol. 28, 111-123, http://dx.doi.org/10.1677/jme.0.0280111.

Dezfuli, B.S., Arrighi, S., Domeneghini, C., Bosi, G., 2000. Immunohistochemical detection of neuromodulators in the intestine of Salmo trutta L. naturally infected with Cyathocephalus truncates Pallas (Cestoda). J. Fish Dis. 23, 265-273, http://dx.doi.org/10.1046/j. 1365-2761.2000.00234.x.

Domeneghini, C., Radaelli, G., Arrighi, S., Mascarello, F., Veggetti, A., 2000. Neurotransmitters and putative neuromodulators in the gut of Anguilla anguilla (L.).
Localizations in the enteric nervous and endocrine systems. Eur. J. Histochem. 44, 295-306

Dumont, Y., Martel, J.C., Fournier, A., St-Pierre, S., Quirion, R., 1992. Neuropeptide $\mathrm{Y}$ and neuropeptide $\mathrm{Y}$ receptor subtypes in brain and peripheral tissues. Prog. Neurobiol. 38, 125-167, http://dx.doi.org/10.1016/0301-0082(92)90038-G.

Forgan, L.G., Forster, M.E., 2007. Effects of potential mediators of an intestinal brake mechanism on gut motility in Chinook salmon (Oncorhynchus tshawytscha). Comp. Biochem. Physiol. C 146, 343-347, http://dx.doi.org/10.1016/j.cbpc.2007.04.007.

Hernández, D.R., Vigliano, F.A., Sánchez, S., Bermúdez, R., Domitrovic, H.A., Quiroga, M.I., 2012. Neuroendocrine system of the digestive tract in Rhamdia quelen juvenile: an immunohistochemical study. Tissue Cell 44, 220-226, http://dx.doi.org/10.1016/j.tice.2012.03.005.

Himick, B.A., Peter, R.E., 1994. CCK gastrin-like immunoreactivity in brain and gut, and CCK suppression of feeding in goldfish. Am. J. Physiol. 267, $841-851$

Holmgren, S., Olsson, C., 2009. The neuronal and endocrine regulation of gut function. In: Bernier, N.J., et al. (Eds.), Fish Neuroendocrinology. Academic Pressure, Amsterdam, pp. 467-512, http://dx.doi.org/10.1016/S1546-5098(09)28010-1.

Hoskins, L.J., Volkoff, H., 2012. The comparative endocrinology of feeding in fish: insights and challenges. Gen. Comp. Endocrinol. 176, 327-335, http://dx.doi.org/10.1016/j.ygcen.2011.12.025.

Image, J 1.41. National Institute of Mental Health, Bethesda. Wayne Rasband of Research Services Branch. Maryland. Available at: http://imagej.nih.gov/ij.

Jensen, J., 2001. Regulatory peptides and control of food intake in non mammalian vertebrates. Comp. Biochem. Physiol. A 128, 471-479, http://dx.doi.org/10.1016/S1095-6433(00)00329-9.

Jensen, J., Holmgren, S., 1994. The gastrointestinal canal. In: Burnstock, G. (Ed.), The Autonomic Nervous System. Harwood Academic/Comparative Physiology and Evolution of the Autonomic Nervous System, Switzerland, pp. 119-167.

Jönsson, A.C., Holmgren, S., Holstein, B., 1987. Gastrin/CCK-like immunoreactivity in endocrine cells and nerves in the gastrointestinal tract of the cod, Gadus morhua, and the effect of peptides of the gastrin/CCK family on cod gastrointestinal smooth muscle. Gen. Comp. Endocrinol. 66, 19-202, http://dx.doi.org/10.1016/0016-6480(87)90267-X.

Jönsson, E., Forsman, A., Einarsdottir, I.E., Egnér, B., Ruohonen, K., Björnsson, B.T., 2006. Circulating levels of cholecystokinin and gastrin-releasing peptide in rainbow trout fed different diets. Gen. Comp. Endocrinol. 148, 187-194, http://dx.doi.org/10.1016/j.ygcen.2006.02.016.

Kamisaka, Y., Totland, G.K., Tagawa, M., Kurokawa, T., Suzuki, T., Tanaka, M., 2001. Ontogeny of cholecystokinin-immunoreactive cells in the digestive tract of Atlantic halibut, Hippoglossus hippoglossus, larvae. Gen. Comp. Endocrinol. 123, 31-37, http://dx.doi.org/10.1006/gcen.2001.7653.

Kamisaka, Y., Kaji, T., Masuma, S., Tezuka, N., Kurokawa, T., Suzuki, T., 2002. Ontogeny of cholecystokinin immunoreactive cells in the digestive tract of bluefin tuna, Thunnus thynnus, larvae. Sarsia 87, 258-262, http://dx.doi.org/10.1080/00364820260294888.

Kamisaka, Y., Drivenes, Ø., Kurokawa, T., Tagawa, M., Rønnestad, I., Tanaka M., Helvik, J.V., 2005. Cholecystokinin mRNA in Atlantic herring, Clupea harengus-molecular cloning, characterization, and distribution in the digestive tract during the early life stages. Peptides 26, 385-393, http://dx.doi.org/10.1016/j.peptides.2004.10.018.

Kehoe, A.S., Volkoff, H., 2007. Cloning and characterization of neuropeptide $\mathrm{Y}$ (NPY) and cocaine and amphetamine regulated transcript (CART) in Atlantic cod (Gadus morhua). Comp. Biochem. Physiol. A 146, 451-461, http://dx.doi.org/10.1016/j.cbpa.2006.12.026.

Kurokawa, T., Suzuki, T., Ando, H., 2000. Development of cholecystokinin and pancreatic polypeptide endocrine systems during the larval stage of Japanese flounder, Paralichthys olivaceus. Gen. Comp. Endocrinol. 120, 8-16, http://dx.doi.org/10.1006/gcen.2000.7512.

Kurokawa, T., Suzuki, T., Hashimoto, H., 2003. Identification of gastrin and multiple cholecystokinin genes in teleost. Peptides 24, 227-235.

Lafont, A.G., Dufour, S., Fouchereau-Peron, M., 2004. Characterisation and distribution of calcitonin gene-related peptide in a primitive teleost, the ee Anguilla anguilla and comparison with calcitonin. Regul. Pept. 117, 141-148, http://dx.doi.org/10.1016/j.regpep.2003.10.018.

Langer, M., Van Noorden, S., Polak, J.M., Pearse, A.G., 1979. Peptide hormonelike immunoreactivity in the gastrointestinal tract and endocrine pancreas of eleven teleost species. Cell Tissue Res. 199, 493-508, http://dx.doi.org/10.1007/BF00236085.

Larhammar, D., 1996. Evolution of neuropeptide Y, peptide YY and pancreatic polypeptide. Regul. Pept. 62, 1-11, http://dx.doi.org/ 10.1016/0167-0115(95)00169-7.

Larhammar, D., Söderberg, C., Lundell, I., 1998. Evolution of the neuropeptide Y family and its receptors. Ann. N.Y. Acad. Sci. 839, 35-40, http://dx.doi.org/ 10.1101/gr.10.3.302.

Lee, J.H., Ku, S.K., Park, K.D., Lee, H.S., 2004. Immunohistochemical study of the gastrointestinal endocrine cells in the Korean aucha perch. J. Fish Biol. 65, 170-181, http://dx.doi.org/10.1111/j. 0022-1112.2004.00442.x.

López-Patiño, M.A., Guijarro, A.I., Isorna, E., Delgado, M.J., Bedate, M.A., Pedro, N., 1999. Neuropeptide $\mathrm{Y}$ has a stimulatory action on feeding behavior in goldfish (Carassius auratus). Eur. J. Pharmacol. 377, 147-153, http://dx.doi.org/10.1016/S0014-2999(99)00408-2.

MacDonald, E., Volkoff, H., 2009. Neuropeptide Y (NPY), cocaine and amphetamine regulated transcript (CART) and cholecystokinin (CCK) in winter skate (Raja ocellata): cDNA cloning, tissue distribution and mRNA 
expression responses to fasting. Gen. Comp. Endocrinol. 161, 252-261, http://dx.doi.org/10.1016/j.ygcen.2009.01.021.

Mai, M.G., Zaniboni Filho, E., 2005. Efeito da idade de estocagem em tanques externos no desempenho da larvicultura do dourado Salminus brasiliensis (Osteichthyes, Characidae). Acta Sci. 27, 287-296, http://dx.doi.org/10.4025/actascianimsci.v27i2.1252.

Martínez-Álvarez, R.M., Volkoff, H., Muñoz-Cueto, J.A., Delgado, M.J., 2008. Molecular characterization of calcitonin gene-related peptide (CGRP) related peptides (CGRP, amylin, adrenomedullin and adrenomedullin-2/intermedin) in goldfish (Carassius auratus): cloning and distribution. Peptides 29, 1534-1543. http://dx.doi.org/10.1016/j.peptides.2008.04.013.

Martínez-Álvarez, R.M., Volkoff, H., Muñoz-Cueto, J.A., Delgado, M.J., 2009. Effect of calcitonin gene-related peptide (CGRP), adrenomedullin and adrenomedullin2 /intermedin on food intake in goldfish (Carassius auratus). Peptides 30, 803-807, http://dx.doi.org/10.1016/j.peptides.2008.12.015.

Min, H., Kai-Yu, W., Yu, Z., 2009. Immunocytochemical Identification and Localization of Diffuse neuroendocrine system (DNES) cells in gastrointestina tract of channel catfish (Ictalurus punctatus). Agric. Sci. China 8, 238-243, http://dx.doi.org/10.1016/S1671-2927(09)60032-8.

Morais Filho, M.B., De Schubart, O., 1955. Contribuição ao estudo do Dorado (Salminus maxillosus) do Rio Mogi Guassu (Pisces, Characidae). Ministério da Agricultura, São Paulo, pp. 1-50.

Narnaware, Y.K., Peter, R.E., 2001. Effects of food deprivation and refeeding on neuropeptide Y (NPY) mRNA levels in goldfish. Comp. Biochem. Physiol. B 129, 633-637, http://dx.doi.org/10.1016/S1096-4959(01)00359-1.

NCBI, National Center for Biotechnology Information. http://www ncbi.nlm.nih.gov/protein

Ogoshi, M., Inoue, K., Naruse, K., Takei, Y., 2006. Evolutionary history of the calcitonin gene-related peptide family in vertebrates revealed by comparative genomic analyses. Peptides 27, 3154-3164, http://dx.doi.org/10.1016 j.peptides.2006.09.011.

Olsson, C., Holmgren, S., 2001. The control of gut motility. Comp. Biochem. Physiol A 128, 481-503, http://dx.doi.org/10.1016/S1095-6433(00)00330-5.

Pan, Q.S., Fang, Z.P., Zhao Huang, F.J., 2000a. Identification, localization and morphology of APUD cells in gastroenteropancreatic system of stomach-containing teleosts. World J. Gastroenterol. 6, 842-847.

Pan, Q.S., Fang, Z.P., Zhao, Y.X., 2000b. Immunocytochemical identification and localization of APUD cells in the gut of seven stomachless teleost fishes. World J. Gastroenterol. 6, 96-101.

Peddu, S.C., Breves, J.P., Kaiya, H., Gordon, Grau, E., Riley Jr., L.G., 2009. Pre and postprandial effects on ghrelin signaling in the brain and on the GH/IGF-I axis in the mozambique tilapia (Oreochromis mossambicus). Gen. Comp. Endocrinol. 161, 412-418, http://dx.doi.org/10.1016/j.ygcen.2009.02.008.

Pinheiro, J.C., Bates, D., 2009. Mixed-Effects Models in S and S-PLUS. Springer Verlag New York Statistics and Computing, 530 pp.

Rodrigues, S., Menin, E., 2008. Anatomia do tubo digestivo de Salminus brasiliensis (Cuvier, 1817) (Pisces, Characidae, Salmininae). Biotemas 21, 65-75, http://dx.doi.org/10.5007/2175-7925.2008v21n2p65.

Rønnestad, I., Rojas, Garcia, C.R., Skadal, J., 2000. Retrograde peristalsis: a possible mechanism for filling the pyloric caeca? J. Fish Biol. 56, 216-218, http://dx.doi.org/10.1111/j. 1095-8649.2000.tb02098.x.
Rønnestad, I., Tonheim, S.K., Fyhn, H.J., Rojas-Garcí, C.R., Kamisaka, Y., Koven, W., Finn, R.N., Terjesen, B.S., Barr, Y., Conceição, L.E.C., 2003. The supply of amino acids during early feeding stages of marine fish larvae: a review of recent findings. Aquaculture 227, 147-164, http://dx.doi.org/10.1016 S0044-8486(03)00500-3.

Rønnestad, I., Kamisaka, Y., Conceição, L.E.C., Morais, S., Tonheim, S.K., 2007. Digestive physiology of marine fish larvae: hormonal control and processing capacity for proteins, peptides and amino acids. Aquaculture 268, 82-97, http://dx.doi.org/10.1016/j.aquaculture.2007.04.031.

SAS Institute, 2000. SAS user's guide. Version 9.1. SAS Institute, Cary.

Shahbazi, F., Karila, P., Olsson, C., Holmgren, S., Jensen, J., 1998. Primary structure, distribution, and effects on motility of CGRP in the intestine of the cod Gadus morhua. Am. J. Physiol. 275, 19-28.

Silverstein, J.T., Shearer, K.D., Dickhof, W.W., Plisetskaya, E.M., 1999, Regulation of nutrient intake and energy balance in salmon. Aquaculture 177, 161-169, http://dx.doi.org/10.1016/S0044-8486(99)00076-9.

Silverstein, J.T., Bondareva, V.M., Leonard, J.B., Plisetskaya, E.M., 2001. Neuropeptide regulation of feeding in catfish, Ictalurus punctatus: a role for glucagon-like peptide-1 (GLP-1). Comp. Biochem. Physiol. B 129(2-3), 623-631, http://dx.doi.org/10.1016/S1096-4959(01)00357-8.

Tarakçi, B.G., 2005. Immunohistochemical identification of peptide hormones in the endocrine cells of the gastrointestinal tract of the Oreochromis niloticus. Turk. J. Vet. Anim. Sci. 29, 207-210.

Toni, R., 2004. The neuroendocrine system: organization and homeostatic role. J Endocrinol. Invest. 27, 35-47.

Vega-Orellana, O.M., Fracalossi, D.M., Sugai, J.K., 2006. Dourado (Salminus brasiliensis) larviculture: weaning and ontogenetic development of digestive proteinases. Aquaculture 252, 484-493, http://dx.doi.org/10.1016/ j.aquaculture.2005.07.002.

Verbeke, G., Molenberghs, G., 2000. Linear Mixed Models for Longitudinal Data. Springer-Verlag, New York.

Vigliano, F.A., Muñoz, L., Hernández, D., Cerutti, P., Bermúdez, R., Quiroga, M.I., 2011. Immunohistochemical study on the gut neuroendocrine system of juvenile pejerrey (Odontesthes bonariensis). J. Fish Biol. 78, 901-911, http://dx.doi.org/10.1111/j. 1095-8649.2011.02912.x.

Vigna, S.R., 2000. Evolution of the cholecystokinin and gastrin peptides and receptors. Am. Zool. 40, 287-295, http://dx.doi.org/10.1093/icb/40.2.287.

Volkoff, H., Canosa, L.F., Unniappan, S., Cerdá-Reverter, J.M., Bernier, N.J., Kelly, S.P., Peter, R.E., 2005. Neuropeptides and the control of food intake in fish. Gen. Comp. Endocrinol. 142, 3-19, http://dx.doi.org/10.1016/j.ygcen.2004.11.001.

Volkoff, H., 2006. The role of neuropeptide Y, orexins, cocaine and amphetamine-related transcript, cholecystokinin, amylin and leptin in the regulation of feeding in fish. Comp. Biochem. Physiol. A 144, 325-331, http://dx.doi.org/10.1016/j.cbpa.2005.10.026.

Webb Jr., K.A., Khan, I.A., Scott Nunez, B., Rønnestad, I., Joan Holt, G., 2010. Cholecystokinin: molecular cloning and immunohistochemical localization in the gastrointestinal tract of larval red drum, Sciaenops ocellatus (L.). Gen. Comp. Endocrinol. 166, 152-159, http://dx.doi.org/10.1016/j.ygcen.2009.10.010.

Yokobori, E., Azuma, M., Nishiguchi, R., Kang, K.S., Kamijo, M., Uchiyama, M., Matsuda, K., 2012. Neuropeptide Y stimulates food intake in the Zebrafish, Danio rerio. J. Neuroendocrinol. 24, 766-773, 10.1111/j.1365-2826.2012.02281.x. 